\title{
FIRMNESS PROFILES ASSOCIATED WITH TIDAL-CREEK DEPOSITS: THE TEMPORAL SIGNIFICANCE OF GLOSSIFUNGITES ASSEMBLAGES
}

\author{
MURRAY K. GINGRAS ${ }^{1}$, S. GEORGE PEMBERTON ${ }^{2}$, AND TOM SAUNDERS ${ }^{2}$ \\ ${ }^{1}$ Department of Geology, University of New Brunswick, P.O. Box 4400, Fredericton, New Brunswick, E3B SA3, Canada \\ ${ }^{2}$ Department of Earth and Atmospheric Sciences, 1-26 Earth Sciences Building, University of Alberta, Edmonton, Alberta T6G 2E3, Canada \\ e-mail:mgingras@ualberta.ca
}

\begin{abstract}
AвSTRACT: Indentation tests are used to detail firmness profiles from intertidal creek deposits and wave-exhumed substrates at Willapa Bay. Both of these sedimentological settings are characterized by occurrences of modern Glossifungites assemblages. Firm substrates associated with the intertidal-creek deposits are derived from dewatered modern sediments, whereas firmgrounds associated with wave erosion consist of dewatered and compacted Pleistocene strata. The Pleistocene firmgrounds are notably firmer than those derived from modern deposits. A strong correlation between sediment firmness and burrowing behavior is evident in these deposits.
\end{abstract}

In tidal-creek systems, the comparatively firm cutbank is characterized by unlined, large-diameter, open burrows that form a Glossifungites assemblage. Intertidal point-bar deposits contain a softground suite consisting of mucous-lined, small-diameter, dominantly vertical traces. Finally, a softground suite of robust, mucous- or mud-lined, vertical and horizontal traces are observed in intertidal-flat deposits. In contrast, Pleistocene firmgrounds generally contain large- and small-diameter traces, with dominantly vertical architectures (Thalassinoides-, Gastrochaenolites-, Diplocraterion-, or Arenicolites-like burrows), depending upon the firmness of the substrate.

Glossifungites occurrences on modern firmgrounds are temporally insignificant, whereas similar occurrences in Pleistocene substrates are temporally significant. Contrasting these two databases suggests that the stratigraphic significance of a Glossifungites-demarcated discontinuity can be assessed in the rock record. Several criteria that are useful for identifying temporally significant surfaces are suggested, including: absence of compaction of the Glossifungites assemblage; presence of well-preserved burrow sculptings; and planar to gently undulatory erosional surfaces as opposed to surfaces with notable topographic relief. Conceptual models demonstrate that muddy substrates potentially require several millennia to compact and dewater. Sandy deposits, on the other hand, have indeterminate significance.

\section{INTRODUCTION}

\section{The Glossifungites Ichnofacies}

Many concepts in ichnology have focused on the identification of key environmental parameters to bolster physical sedimentologic data for the interpretation of sedimentary facies in the rock record. Some of the variables that ichnologists have successfully characterized include oxygenation, salinity, and sedimentation rates. Though trace fossils were thought to be useful in delineating the internal architecture of sedimentary accumulations, their utility for the identification of key stratigraphic horizons was limited to trace-fossil stratigraphy (Crimes 1968; Seilacher 1970). The evolution of genetic stratigraphic models forced a shift in focus from the resolution of facies geometry to the correlation of genetically significant surfaces. This emphasis led to the recognition that certain horizons, such as sequence boundaries and transgressive surfaces of erosion, might be demarcated by the presence of a suite of trace fossils characteristic of the Glossifungites ichnofacies (Pemberton and Frey 1985; MacEachern et al. 1992; Pemberton et al. 1992; Pemberton and MacEachern 1995).

The Glossifungites ichnofacies consists of traces that were emplaced into a firm substrate. Because of their cohesive nature, firmgrounds support open, unlined burrows that would otherwise relax and collapse in a softer substrate. Firmgrounds in clastic substrates are typically derived from sediment that has undergone burial, compaction, and dewatering, or subaerial exposure. Exhumation of buried substrates, through autocyclic or allocyclic processes, is required to expose compacted firmgrounds to the activities of burrowing animals. Linking Glossifungites-demarcated discontinuities (hitherto referred to as "Glossifungites surfaces") to potential changes in base level provides the basis for the sequence stratigraphic significance of the Glossifungites ichnofacies. This is because the presence of a Glossifungites surface is evidence for a break between erosion and deposition across a surface (Pemberton and MacEachern 1995). Unfortunately, this concept can be misapplied, because the presence of a Glossifungites surface alone divulges no information of stratigraphic value (Pemberton and MacEachern 1995). Like other sedimentary facies, the Glossifungites ichnofacies must conform to Walther's Law and have identifiable, mappable extents.

Seilacher (1964) originally described the Glossifungites ichnofacies as a mainly littoral assemblage of trace fossils emplaced in cohesive substrates. These are markedly different from the Skolithos ichnofacies that characterize settings with shifting substrates. Frey and Seilacher (1980) restricted the Glossifungites ichnofacies to firmgrounds in marine environments, though the essential components of Seilacher's original (1964) definition remained intact. Working along the Georgia coast, Pemberton and Frey (1985) provided numerous examples of burrowed firmgrounds in a variety of modern settings. Moreover, their study was the first to link processes, such as wave erosion, to the development of Glossifungites surfaces. These observations ultimately led to the integration of ichnology and genetic stratigraphy (MacEachern et al. 1992; Pemberton et al. 1992; Pemberton and MacEachern 1995).

Although firmground assemblages are well understood, the Glossifungites concept generates a great deal of confusion amongst researchers. This is because firmgrounds represent an intermediate and gradational state between softgrounds and hardgrounds. There is no "rule of thumb" with which one can determine the degree of compaction and dewatering a substrate has endured in the transformation from a softground to a firmground. Although the stratigraphic significance of Glossifungites surfaces is well recognized, their dependence on physical parameters such as grain size, water content, and sedimentation rates has yet to be reviewed in the geological literature. Admittedly, establishing acceptable criteria from which the compactional parameters of a firmground might be derived is an all but impossible task. In addition to the aforementioned parameters, organic content, grain sorting, grain shape, and initial pore pressure undoubtedly have a notable effect on the kinetics of the compaction process (Krumbein 1959; Hoyt and Henry 1964; Tokunaga et al. 1994; Dewherst and Aplin 1998).

This research attempts to profile firmness changes in a dynamic depositional environment that is characterized by the presence of soft and firm substrates. The measurements and observations procured from the field are interpreted in the light of their temporal significance and provide a basis for application to the rock record. In other words, can we distinguish significant Glossifungites surfaces from less significant ones? This paper also details sedimentological and biological relationships, as they relate to firmness changes across a tidal-creek deposit. A tertiary objective is to provide conceptual and empirical bases for future research directed towards under- 


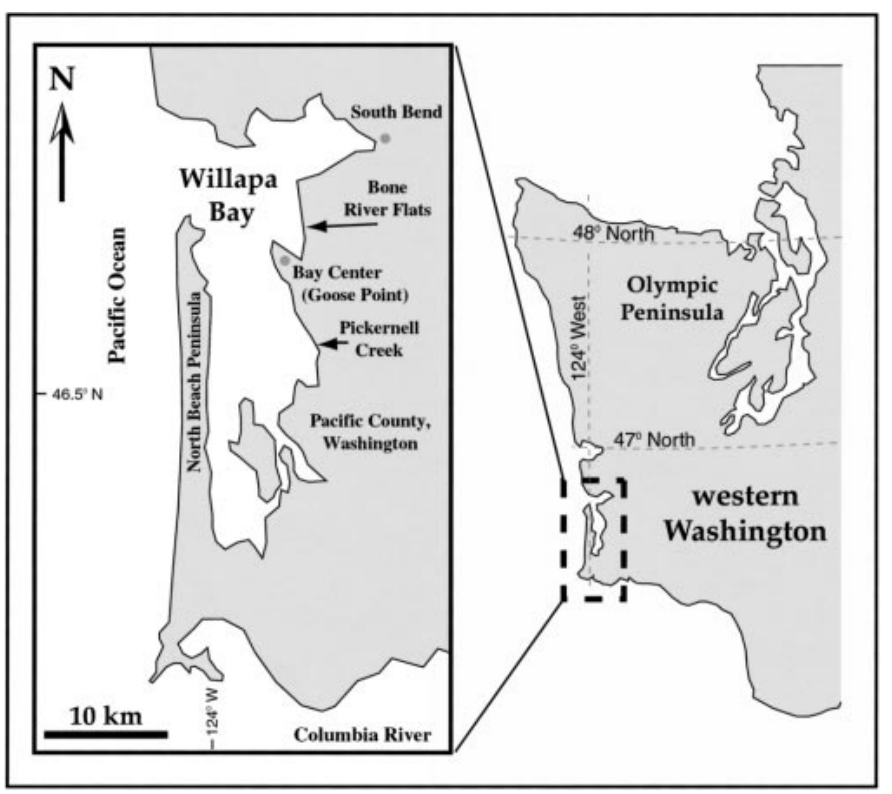

FIG. 1.-Location map of Willapa Bay, Washington.

standing the stratigraphic significance of Glossifungites surfaces. An intertidal-creek and point-bar depositional environment was chosen because substrate consistencies change notably from the point bar to the cutbank. Also, the intertidal creek cuts into the intertidal flat, allowing deeper sampling of the intertidal-flat deposits. These data are contrasted with Glossifungites surfaces associated with wave erosion along the eastern margin of Willapa Bay.

\section{Study Area}

Willapa Bay is located in the southwest corner of Washington (Fig. 1). The bay is separated from the Pacific Ocean by the North Beach Peninsula, a spit $27 \mathrm{~km}$ long derived from sand transported from the mouth of the Columbia River (Clifton and Phillips 1980). The bay is sheltered from ocean waves by the North Beach Peninsula and Willapa Bar, a set of shoals at the bay mouth. Willapa Bay is a mesotidal estuary with a tidal range of 2 to $3 \mathrm{~m}$. The tidal prism, which exceeds $700,000 \mathrm{~m}^{3}$, constitutes about $45 \%$ of the bay's total volume (U.S. Army Corps of Engineers 1975).

The data presented in this study were collected primarily from the extensive sandflats and mudflats adjacent to the Bone River and Goose Point (Fig. 1). At these locations the intertidal flats are easily accessed from Highway 101, and they afford many excellent exposures of modern intertidal-creek deposits.

\section{Methods}

Detailed descriptions of modern intertidal-creek and intertidal-flat deposits were compiled from various datasets. These comprise manual trenching, box coring, and tube coring. Several resin casts of modern traces were also poured to aid in the identification and interpretation of the biogenic structures.

The methodology for the firmness test was derived from the standard Brinell hardness test, a metallurgical technique (Brinell 1900; Gingras, unpublished data). The modified Brinell firmness test is simple, and the procedure provides consistent results. These characteristics are particularly well suited to the collection of field data.

Firmness tests were taken from cylindrical cores extracted from the intertidal-flat, cutbank, channel, and point-bar subenvironments. The core was subsequently split, and the center, least-disturbed sediment, was firmness- tested. In an effort to extract core from greater depths, small holes were dug and coring commenced from the bottom of the hole. In such cases the upper $10-20 \mathrm{~cm}$ of the core were not considered in the firmness testing.

\section{RESULTS}

\section{Intertidal-Creek Deposits}

Extensive networks of meandering intertidal creeks commonly dissect the modern intertidal flats. This is particularly true of substrates with high mud content. Point-bar deposits, channel lags, and cutbank exposures are associated with these channels. Modern intertidal point bars at Willapa Bay are typically burrowed by an extremely low-diversity assemblage of diminutive infauna. Threadworms, such as the capitellid polychaete Heteromastus, are among the most common burrowers in this environment. Heteromastus burrows consist of small-diameter, vertical shafts 10 to $30 \mathrm{~cm}$ deep, with numerous horizontal branches. Although the overall trace geometry is Skolithos- or Trichichnus-like, the termini of the main vertical shaft and many of the branches are commonly demarcated by Gyrolitheslike coils. Other trace makers present in intertidal point bars include: Neries, a polychaete that produces Palaeophycus- and Planolites-like burrows; the small amphipod Corophium, which makes Diplocraterion-like traces; and juvenile bivalves whose siphonate trace most resembles Skolithos, Siphonites, or fugichnia. This assemblage grades with the intertidal-flat suite over a distance of $2 \mathrm{~m}$ on smaller point bars and up to $8 \mathrm{~m}$ on larger point bars. Open burrows present in the point-bar and intertidal-flat deposits have small diameters, and are generally mucous- or mud-lined. Unlined traces collapse following the passage of the trace maker. Several large-diameter $(>7 \mathrm{~mm})$ shafts are present in the intertidal-flat deposits. These are normally thickly lined, as with the Rosselia-like burrows of terebellid polychaetes, or are constantly re-excavated or reamed, such as those traces produced by large bivalves (such as Tresus nuttallii). In both intertidal-flat and point-bar deposits, no large, open, unlined burrows are present; a Glossifungites-like ichnocoenosis is therefore not developed in these accumulations.

Deposition in the channel is restricted to a shell lag 5-10 cm thick overlying a sharp, erosional contact. Very few burrowers are present below the shelly accumulation, except rare numbers of Neries, Nephtys, and Heteromastus. Although the substrate at the channel base is relatively consolidated, no large burrows that might constitute a Glossifungites assemblage are present. Shifting of the channel lag may preclude the construction of such semipermanent domiciles.

The cutbanks along the intertidal creeks at the Bone River location expose intertidal-flat lamination, point-bar stratification, basal channel scours, and channel lag deposits (Fig. 2). Drainage along the cutbanks is enhanced, and the partially dewatered substrate supports large, unlined, open, Psilonichnus-like burrows of the crab Hemigrapsus oregonensis. This ichnocoenosis is of a limited extent and is confined to the exposed parts of the cutbank and the adjacent intertidal flat. It displays, however, all the salient characteristics of a Glossifungites assemblage.

The firmness measurements associated with the intertidal-creek depositional environment range from approximately $8 \times 10^{3} \mathrm{~Pa}$ to $1.8 \times 10^{5} \mathrm{~Pa}$ (Figs. 3, 4). The contoured firmness profile (Fig. 3) shows that zones of relative firmness persist along the intertidal cutbank and the channel base. Streaks of comparatively soft substrate approximately follow the clinoform geometry of the point bar. The maximum firmness $(178 \mathrm{kPa})$ is typically intersected almost $2.4 \mathrm{~m}$ below the mean elevation of the intertidal flat. This horizon, though intersected only in four of the nine cores because of the sampling constraints, is presumably present throughout the study site. Some anomalous soft zones are present in the intertidal deposits adjacent to the cutbank (Fig. 3), possibly the result of uneven drainage. Otherwise, the contoured data are consistent with the depositional architecture of this subenvironment. The firmness measurements can also be compared favorably to the empirical observations outlined in the previous section. 


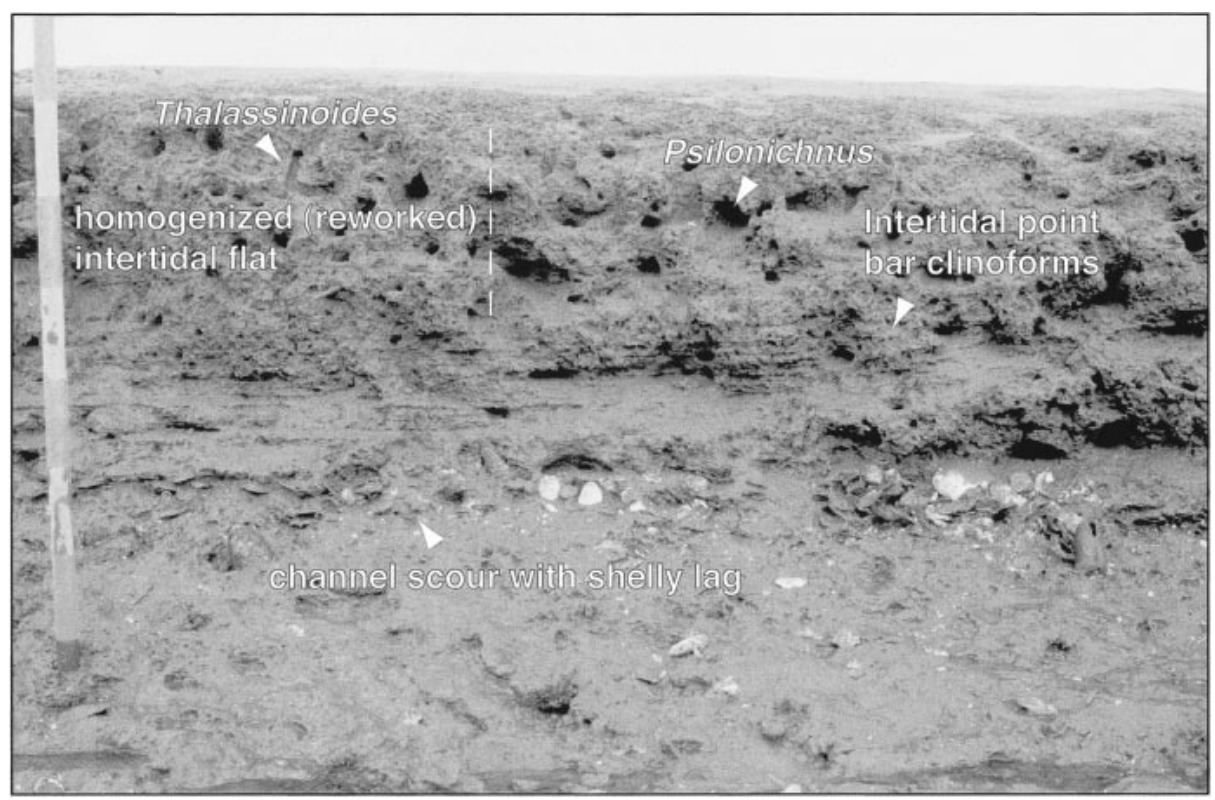

FIG. 2.-A cutbank exposure associated with an intertidal runoff creek. In this section a channel scour overlain by laminated point-bar deposits is visible. The poorly bedded sediment results from bioturbation associated with the intertidal-flat deposit. Facies characteristic of intertidal deposits normally prograde over intertidal point-bar accumulations. The Psilonichnus- and Thalassinoides-like traces are related to colonization of the dewatered cutbank, as opposed to the intertidal-flat depositional environment.

\section{Wave-Eroded Glossifungites-Demarcated Discontinuities}

Along the eastern margin of Willapa Bay, exhumed firmgrounds are generally present from Goose Point to Pickernell Creek (Fig. 1). Unlike the firm substrates associated with the cutbanks of intertidal creeks, the wave-eroded sediments consist of Pleistocene mud. These muds are stiffer than any modern firm substrates observed, typically firmer than $10^{7} \mathrm{~Pa}$ and locally exceeding $10^{9} \mathrm{~Pa}$. The maximum firmness of modern sediments is about $10^{5} \mathrm{~Pa}$. Although the range of firmness values spans several orders of magnitude, the firmness is largely substrate-specific. The values are contingent on the texture of the sediment and the age of the Pleistocene deposit. Older Pleistocene strata, which have not been reliably dated, have firmness values on the order of $10^{8}$ to $10^{9} \mathrm{~Pa}$ (Table 1; Fig. 4). Younger Pleistocene strata were deposited approximately 100-200 ka (Kvenvolden et al. 1979). These generally exhibit firmness measurements that are closer to $10^{7} \mathrm{~Pa}$ (Table 1, Fig. 4).

Locally, the firmness profiles are remarkably homogeneous. Indent diameters in fresh surfaces of the compacted Pleistocene sediment generally vary within $0.5 \mathrm{~mm}$. In fact, measurements taken within texturally similar deposits of similar age show little variability overall.

In the lower intertidal zone, relatively softer Pleistocene muds are generally colonized by the burrowing mud shrimp Upogebia pugettensis. Their traces are decidedly Thalassinoides-like (Fig. 5), and the burrow density can be notably high (commonly exceeding 100 individuals $/ \mathrm{m}^{2}$ ). In the upper intertidal, Polydora is the dominant burrower (Fig. 5). These small spionid worms reside in diminutive Diplocraterion-like structures and are present in very high population densities (up to 30,000 individuals $/ \mathrm{m}^{2}$ ). Where the Polydora burrow density is extreme, the exposed firmground is softer $\left(\approx 10^{5} \mathrm{~Pa}\right.$; Table 1$)$. This is thought to be due to mechanical weakening of the burrowed sediment. Bioturbation related to the mud shrimp does not lower the firmness of the substrate at the scale measured.

Indent averages are based on a minimum of five drop tests. Maximum deviation from the mean is $0.5 \mathrm{~mm}$, but most measurements fall \pm 0.25 $\mathrm{mm}$ from the mean.

Older, firmer Pleistocene substrates are generally not burrowed by crustaceans. In the middle intertidal zone, the bivalve Petricola pholadiformis is the dominant tracemaker (Fig. 5). Their traces have a clavate shape and are most similar to the hardground trace fossil Gastrochaenolites. Polydora dominantly colonizes the upper intertidal, generally in lower population densities than with the younger Pleistocene substrates (0 to 7000 individuals $/ \mathrm{m}^{2}$ ). Encrusting anenomes and barnacles are also common in this zone.

Little relief has been observed on exhumed Pleistocene firmgrounds. They are generally planar to the sea-cliff edge, where they abruptly and smoothly ramp upwards (Fig. 5). Topography on these surfaces most commonly results from the weathering of stratification or wood clasts.

Traces observed in these substrates are unlined or very thinly lined. Sculptings are generally exquisitely detailed and have a high preservation potential. Several burrows were revisited over three seasons and were essentially unchanged from previous years. The sediment shows no sign of relaxation and collapse. All observations in the modern suggest that these burrows would pass into the geological record with essentially no taphonomic disturbance.

\section{DISCUSSION}

\section{Animal-Sediment Relationships}

Empirical observations of burrow architecture and substrate consistency across the intertidal creek closely match the data collected using the modified Brinell firmness tests. Sediments on the point bar and transitional intertidal flat are relatively soft (approximately $7 \times 10^{3} \mathrm{~Pa}$ to $1.5 \times 10^{4}$ Pa; Fig. 3). Here the only open traces present include small- to moderatesized, mucous-lined shafts and burrows. In the intertidal flat, some larger burrows, such as those of terebellid polychaetes, are present; these require a cohesive, thickened lining to remain open in the relatively soft substrate. Other large-diameter burrows, such as those excavated by robust bivalves, require regular reaming to maintain an open conduit to the sediment-water interface.

Point-bar deposits represent the "softest" accumulations of sediment from the substrates tested. High sedimentation rates, which are characteristic of many point-bar deposits, may promote elevated pore-water content. Abundant bioturbators, such as Heteromastus, contribute to the overall soft consistency of this depositional subenvironment. Intertidal-flat deposits are characterized by lower sedimentation rates than adjacent point-bar accumulations. Their softness, however, is greatly enhanced by abundant burrowing fauna, the activities of which significantly increase the pore-water content of the substrate (Cadée 1998).

Those most familiar with intertidal flats have probably noted that the 


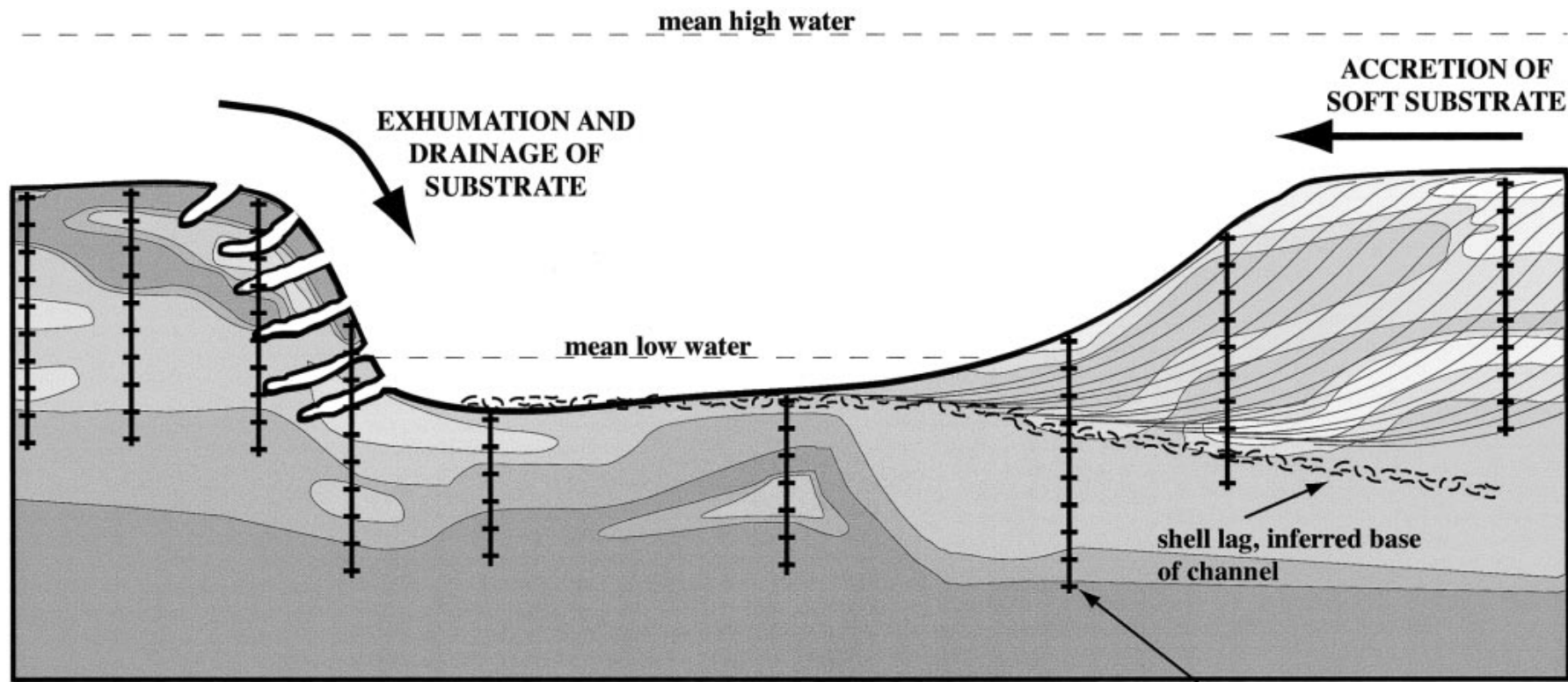

LEGEND Substrate Firmness (Pascal)

sample intervals indicated $=15 \mathrm{~cm}$

appx. 7.0E + 03 Pa

appx. 1.5E + 04 Pa

appx. 2.5E + $04 \mathrm{~Pa}$ appx. 4.0E + 04 Pa

appx. 8.0E + 04 Pa

$>1.2 \mathrm{E}+05 \mathrm{~Pa}$

FIg. 3.-Schematic cross section of firmness profiles from an intertidal runoff creek at Willapa Bay. Notable features of this diagram include the following: a strong correlation between the subenvironments (intertidal flat, point bar, channel, and cutbank) and cohesiveness of the substrate; marked heterogeneity of firmness profiles; and, the presence of a Glossifungites ichnocoenose in the area of the cutbank.

cutbanks adjacent to intertidal creeks proffer the easiest wadlopen (following the Dutch enthusiasm for mud-walking). This is reflected in the firmness measurements collected from the channel and cutbank. Measurements within the channel are typically between $5 \times 10^{4}$ and $6.5 \times 10^{4} \mathrm{~Pa}$ (Fig. 3 ). Firmness assessments from the cutbank are similar, although they locally approach $9 \times 10^{4} \mathrm{~Pa}$ (Fig. 3). Large, open burrows that would have the taphonomic characteristics of the Glossifungites ichnofacies are present where the firmness exceeds 5 to $6 \times 10^{4} \mathrm{~Pa}$. Although the channel base appears firm enough to support similar, unlined burrows, very few traces are actually present. This may be due to a shifting detrital veneer on the exhumed substrate that precludes the construction of semipermanent domiciles. Another explanation is that the shelly channel lag acts as a barrier to larger burrowing organisms.

The firmness profiles derived in and around the intertidal creek indicate that patterns of deposition and drainage associated with the intertidal creek strongly control the firmness of the associated substrates. Along the cutbank, where the best drainage is afforded, the substrate is significantly firmer. Reduced pore pressure in the area of the cutbank is accentuated because the cutbank is virtually devoid of bioturbating infauna. The absence of these organisms is the result of higher current energy, which removes resuspendable, nutrient-rich surface detritus (Whitehouse and Michener 1998), as well as enhanced drainage of the substrate. Ultimately, the paucity of effective bioturbators precludes the introduction of additional pore water into the substrate.

The patchy distribution of infauna is strongly controlled by the firmness of the substrate and the rate of sedimentation or erosion (Bromley 1996; Cadée 1998). Cutbank, channel, point bar, and intertidal flat each exhibit strikingly different trace assemblages: the cutbank is characterized by Psi- lonichnus- and Skolithos-like burrows; point-bar deposits commonly contain small Gyrolithes-, Planolites-, Palaeophycus-, Arenicolites-, and Skolithos-like traces; and intertidal-flat accumulations are distinguished by larger-diameter Thalassinoides-, Rosselia-, Planolites-, Palaeophycus-, Arenicolites-, and Skolithos-like architectures. Channel deposits are essentially unburrowed. These distribution patterns demonstrate the dependence of bioturbate texture on certain sedimentological parameters (cohesiveness and sediment aggradation rate, in this case).

Far from being homogeneously distributed, firm "patches" are sporadically present in vertical profile (Fig. 3). In deposits passing from the modern to the historical record, this heterogeneity is pronounced. Hydraulic erosion of the modern deposits at Willapa Bay therefore produces notable decimeter-scale topography (Fig. 6). In contrast, older deposits, such as the Pleistocene mud exposed at Willapa Bay, have strikingly homogeneous firmness profiles. At the bay, wave erosion of Pleistocene muds typically produces a planar surface (Fig. 5F). Homogeneity of firmness may be the best indicator of burial and compaction. Substrates that are subjected to drainage or desiccation tend to dewater unevenly. Undulatory (decimeterscale) Glossifungites surfaces are therefore most likely attributable to minor erosional surfaces; planar to undulatory (meter-scale) horizons are more indicative of longer burial histories and significant erosion.

\section{Stratigraphic Significance}

The Glossifungites ichnofacies is increasingly recognized as being indicative of diastems or surfaces that may have stratigraphic significance in the rock record (Pemberton and Frey 1985; MacEachern et al. 1992). Although there is general agreement about how these surfaces form, the depth 


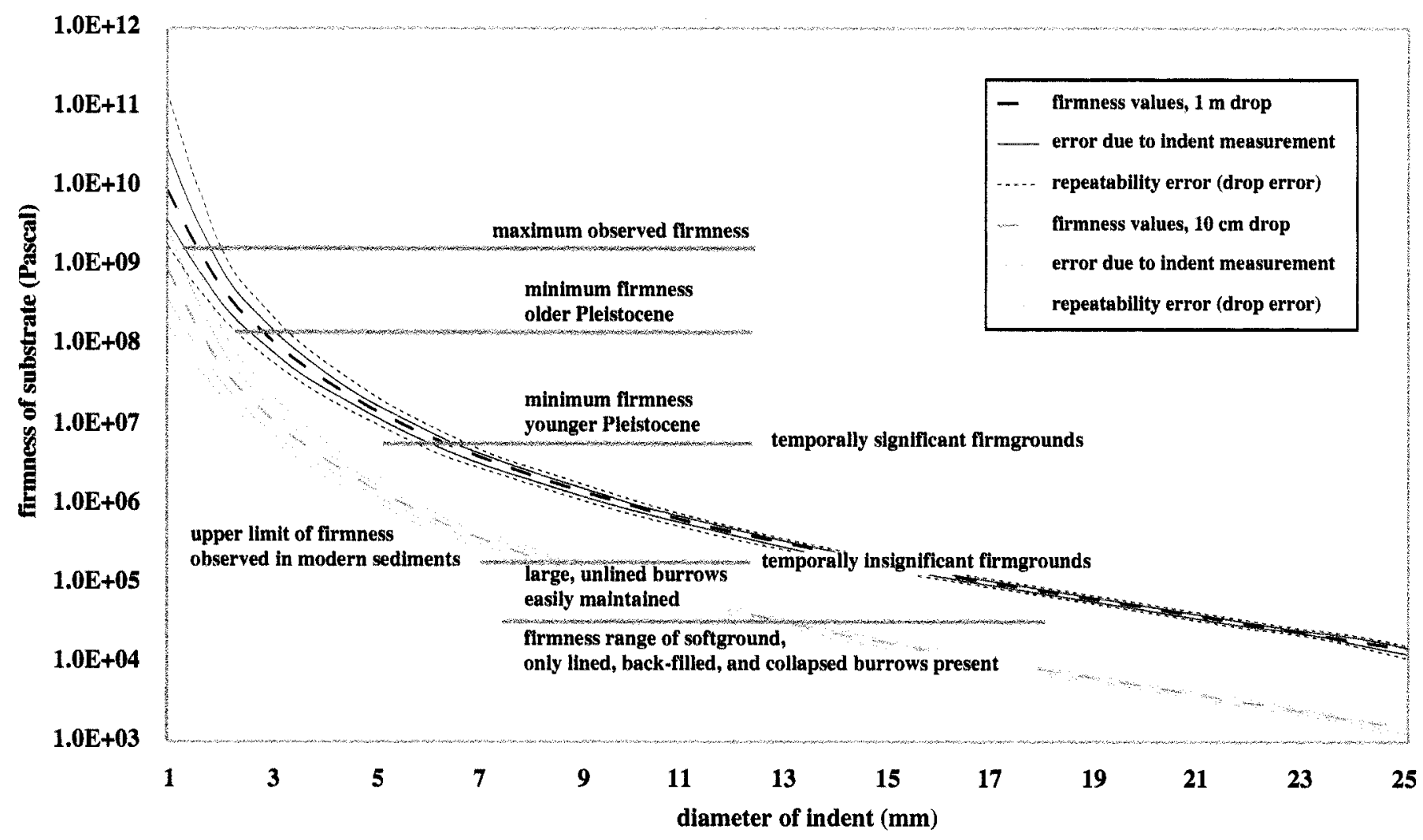

FIG. 4.-Graph of the pressure exerted by the substrate vs. the diameter of the indentation made during the firmness test. The upper curve estimates the pressure produced by an indenter based on a $1 \mathrm{~m}$ free fall; the lower curve indicates pressure values produced from a $10 \mathrm{~cm}$ drop. Error margins are indicated by the thinner lines. Values for exhumed Pleistocene substrates generally exceed $10^{7} \mathrm{~Pa}$; Glossifungites burrows into modern sediments can be maintained where the substrate cohesiveness is greater than $6 \times 10^{4} \mathrm{~Pa}$. Firmness values between $10^{5}$ and $10^{7} \mathrm{~Pa}$ are not recorded at Willapa Bay. They represent the temporally significant gap for sediments that are not desiccated.

of burial required to compact the sediment sufficiently to produce a firmground is uncertain. In fact, the depth required varies with sediment texture (Fig. 7A,B), initial pore-water content, sedimentation rate, and length of time that the substrate was buried (Dewherst and Aplin 1998).

Consider, for example, the contrasting hydraulic conductivity of muddy versus sandy deposits. The range of hydraulic conductivities of muddy substrates at Willapa Bay falls between $10^{-7}$ and $10^{-4} \mathrm{~cm} / \mathrm{s}$ (measured with a standard Darcy laboratory experiment). Sandy substrates, on the other hand, generally measure between $10^{-2}$ and $10^{-1} \mathrm{~cm} / \mathrm{s}$. The contrast in hydraulic conductivities, then, is between 2 to 8 orders of magnitude. Darcy's Law dictates that the volumetric flow rate is directly proportional to the hydraulic conductivity of the matrix. Potentially, the dewatering of muddy substrates takes 2 to 8 orders of magnitude longer than sandy examples (Fig. 7B). Surf-pounded beaches, which are typically cohesive

TABLE 1.-Summary of firmness data for exhumed Pleistocene mud.

\begin{tabular}{lcc}
\hline \hline $\begin{array}{c}\text { Pleistocene Substrates } \\
\text { Substrate Type }\end{array}$ & Indent avg. (mm) & Firmness (Pa) \\
\hline Young Pl mud a & 6 & $9.0 \mathrm{e}+06$ \\
Young Pl mud a (burrowed) & 11.5 & $6.0 \mathrm{e}+05$ \\
Young Pl mud b & 7 & $7.0 \mathrm{e}+06$ \\
Young Pl mud c & 5.2 & $1.5 \mathrm{e}+07$ \\
Young Pl mud d & 5.5 & $1.0 \mathrm{e}+07$ \\
Young Pl mud e & 6.8 & $6.0 \mathrm{e}+06$ \\
Old Pl mud a & 2.8 & $2.0 \mathrm{e}+08$ \\
Old Pl mud b & 3.1 & $1.0 \mathrm{e}+08$ \\
Old Pl mud c & 2.2 & $7.0 \mathrm{e}+08$ \\
Old Pl mud c (burrowed) & 2.3 & $6.0 \mathrm{e}+08$ \\
Old Pl sandy mud c & 1.9 & $1.0 \mathrm{e}+09$ \\
\hline
\end{tabular}

enough to support the weight of an automobile, are an excellent example of how quickly firm substrates can be developed in sandy deposits. Conversely, well-indurated muds, such as the Pleistocene muds at Willapa Bay, (e.g., exceeding $10^{7} \mathrm{~Pa}$; Fig. 4) probably take centuries or millennia to compact and dewater. This temporal scale is consistent with the observations of Pemberton and Frey (1985) at St. Catherine's Island, where the exposed firmground was dated to $1.5 \mathrm{ka}$.

The results of this study show that sandy mud is firm enough to preserve open burrows with surface sculptings where firmness exceeds approximately $8 \times 10^{4} \mathrm{~Pa}$. Although these traces are characteristic of Glossifungites assemblages, the plasticity of the substrate suggests that these traces are subject to some compaction following burial. Exhumed Pleistocene mud is comparatively firm. Because these substrates were previously dewatered and compacted, they are subject to far less compaction upon passage back into the historical record. Well-preserved sculptings and undeformed burrow architectures are strongly indicative of burrows that were excavated in substantially dewatered and compacted sediment. It should be noted that desiccated substrates may also be firm to hard. In such sediments, sedimentological evidence, such as the presence of desiccation cracks and salt casts, must serve to differentiate subaerially exposed sediments from those that were exhumed. Also, sediments that are prone to subaerial exposure are commonly inhospitable to softground burrowers. With the exception of vertebrate burrows, a palimpsest suite of trace fossils is therefore not expected in desiccated substrates.

Although this study demonstrates many of the mechanisms associated with the development of Glossifungites assemblages, it does not directly address the problem of generating a widespread Glossifungites surface. The 

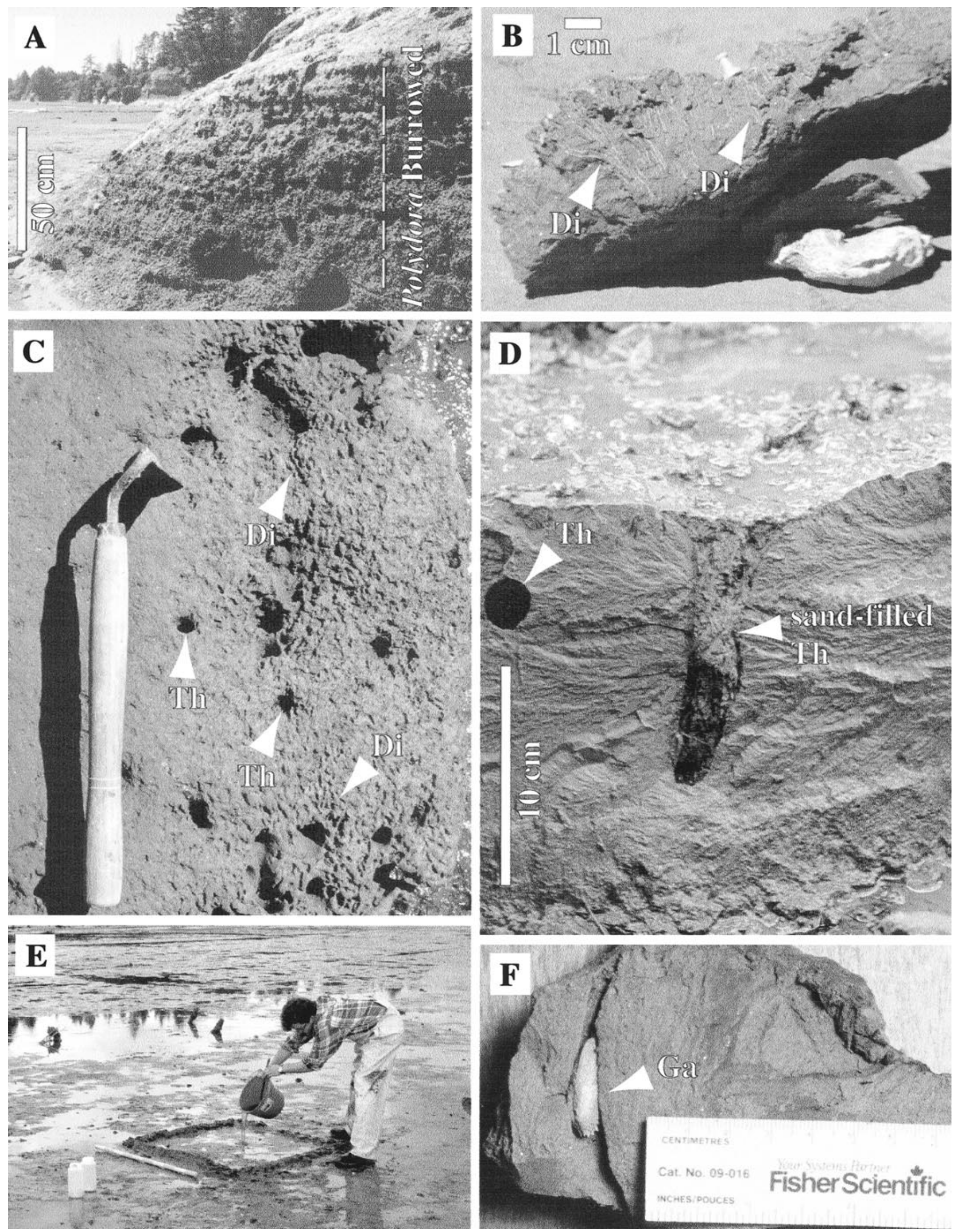


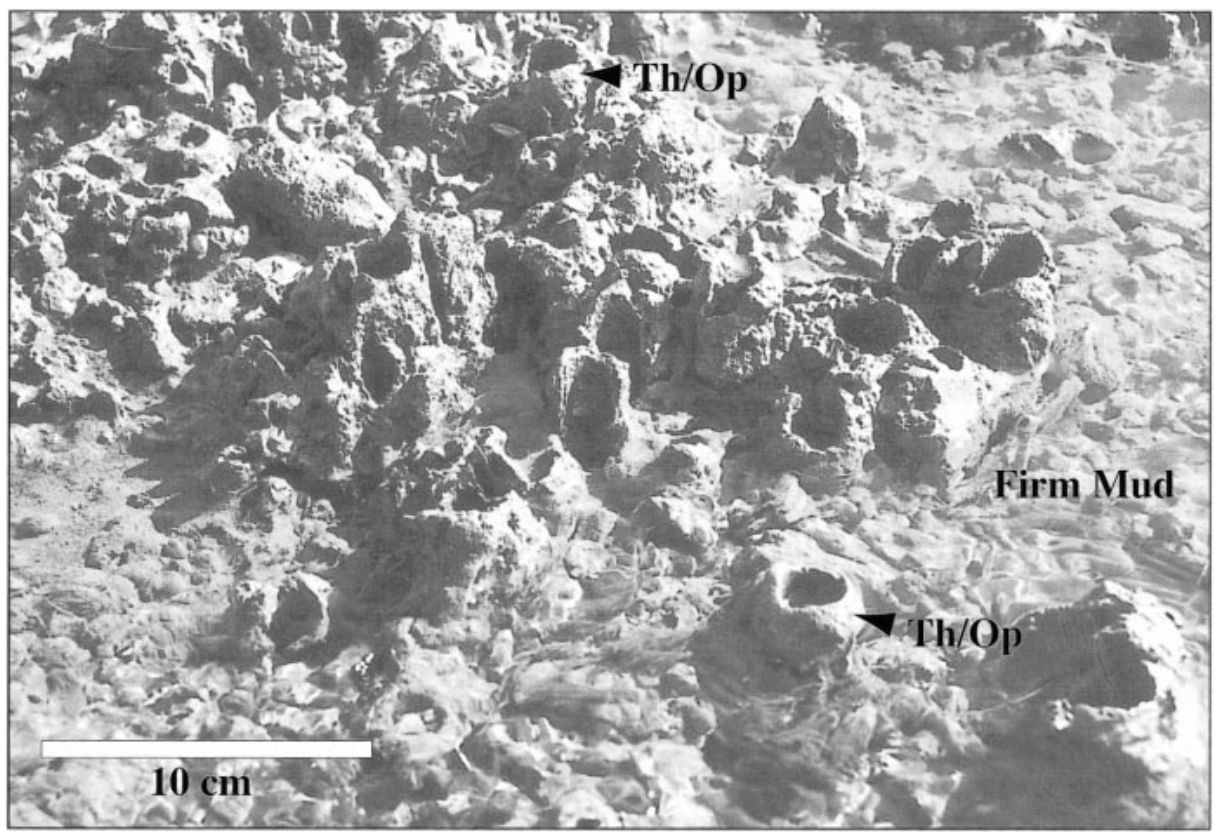

FIG. 6.-Undulatory topography in a burrowed, exhumed, muddy interbed. The mud is modern and generally has a firmness of $10^{5}$ $\mathrm{Pa}$.

cutbank is areally restricted and has a low preservation potential. For these reasons it is unlikely that a cutbank-associated suite of traces could produce a mappable Glossifungites surface. The firmest substrate observed at the Bone River location, however, is present 2 to $2.5 \mathrm{~m}$ below the surface of the intertidal flat (Fig. 3). At this depth, the firmness exceeds $1.2 \times 10^{5}$ $\mathrm{Pa}$. Therefore, erosion to a depth of $2 \mathrm{~m}$ would be required to produce a mappable Glossifungites surface. This could be accomplished either by rapid tidal-creek migration or by wave ravinement, possibly in conjunction with base-level change. Burrows into this surface would be susceptible to postdepositional compaction and therefore distinguishable from those emplaced in Pleistocene deposits. At the bay, mappable Glossifungites surfaces typically occur in Pleistocene strata that have been exposed by intertidal wave erosion. These include many examples of uncompacted (temporally significant) Glossifungites assemblages that are present in the Pleistocene sediment (Fig. 5E). Common burrows in these deposits include Thalassinoides-, Skolithos-, Diplocraterion-, and Arenicolites-like traces. In less cohesive deposits, such as on intertidal cutbanks, Psilonichnus- and Skolithos-like burrows are most common.

In summary, not all Glossifungites-demarcated discontinuities are significant omission surfaces. This observation is well documented by previous researchers (Pemberton and Frey 1985; MacEachern et al. 1992; Pemberton and MacEachern 1995). Assemblages of undeformed trace fossils that descend into compacted, muddy substrates are more likely to be temporally significant and probably represent century- to millennia-scale burial histories. Somewhat deformed Glossifungites assemblages more likely denote decade- to century-scale histories. Sandy firmgrounds, on the other hand, have indeterminate temporal significance. As noted earlier, undulatory (decimeter-scale) Glossifungites surfaces are most commonly associated with minor erosion, whereas planar to gently undulatory horizons are suggestive of long burial histories and significant erosion. This conclusion is demonstrated in the modern deposits at Willapa Bay, and reflects homogeneity of firmness profiles following prolonged sediment compaction.

Glossifungites surfaces must be laterally extensive and mappable if they are to provide improved stratigraphic resolution. At Willapa Bay, a $2 \mathrm{~m}$ lowering of base level would be required to expose mudflat deposits firm enough to develop a mappable Glossifungites surface. This surface would probably be subject to postdepositional compaction and be characteristically undulatory and, by the criteria outlined in this paper, not be temporally significant. More indurated firmgrounds consist of exhumed Pleistocene muds. These exhumed deposits form more or less planar surfaces, and can be mapped for several kilometers along the bay's eastern margins. The temporal significance of the depositional hiatus represented by these surfaces spans 100-200 ka (Kvenvolden et al. 1979), and is the result of large fluctuations of relative sea level (Dupré et al. 1991).

\section{CONCLUSIONS}

Firmness measurements derived from the modified Brinell hardness test provide profiles that are consistent with empirical observations along the tidal creek. As a simple field method it provides the opportunity to compare other occurrences of modern Glossifungites surfaces. The firmness profile associated with the tidal-creek deposit correlates strongly with changes in burrowing behavior. Dewatered substrates adjacent to the cutbank are most commonly occupied by crustaceans, in this case Hemigrapsus oregonensis. Burrowing worms are generally rare, although small Heteromastus and spionids successfully colonize this zone. Soft substrates along the point bar typically contain a low-diversity assemblage of burrowing worms, whereas the soft to intermediate substrates of the intertidal flat support diverse assemblages of polychaetes, crustaceans, and bivalves. The resulting ichnofacies are quite distinctive and variable. The cutbank is characterized by

$\leftarrow$

FIG. 5.-A) Younger Pleistocene firmground that is intensely burrowed by Polydora. B) A sectional view of the small Diplocraterion-like burrows (Di) that are constructed by Polydora. In this case, the causative burrows are filled with fine sand, and the spreite are not apparent because of the scale of the photograph. C) Large-diameter Thalassinoides (Th) excavated in firmgrounds by Upogebia. Plan view of the burrows of Polydora (indicated by Di) are also apparent. D) Sectional view of the Thalassinoides-like trace shown in Part C. The vertical shaft is sand-filled. E) A Petricola-dominated firmground in the middle intertidal zone. Note the extremely low relief of this surface. F) Clavate, Gastrochaenolites-like burrow of Petricola pholadiformis. 

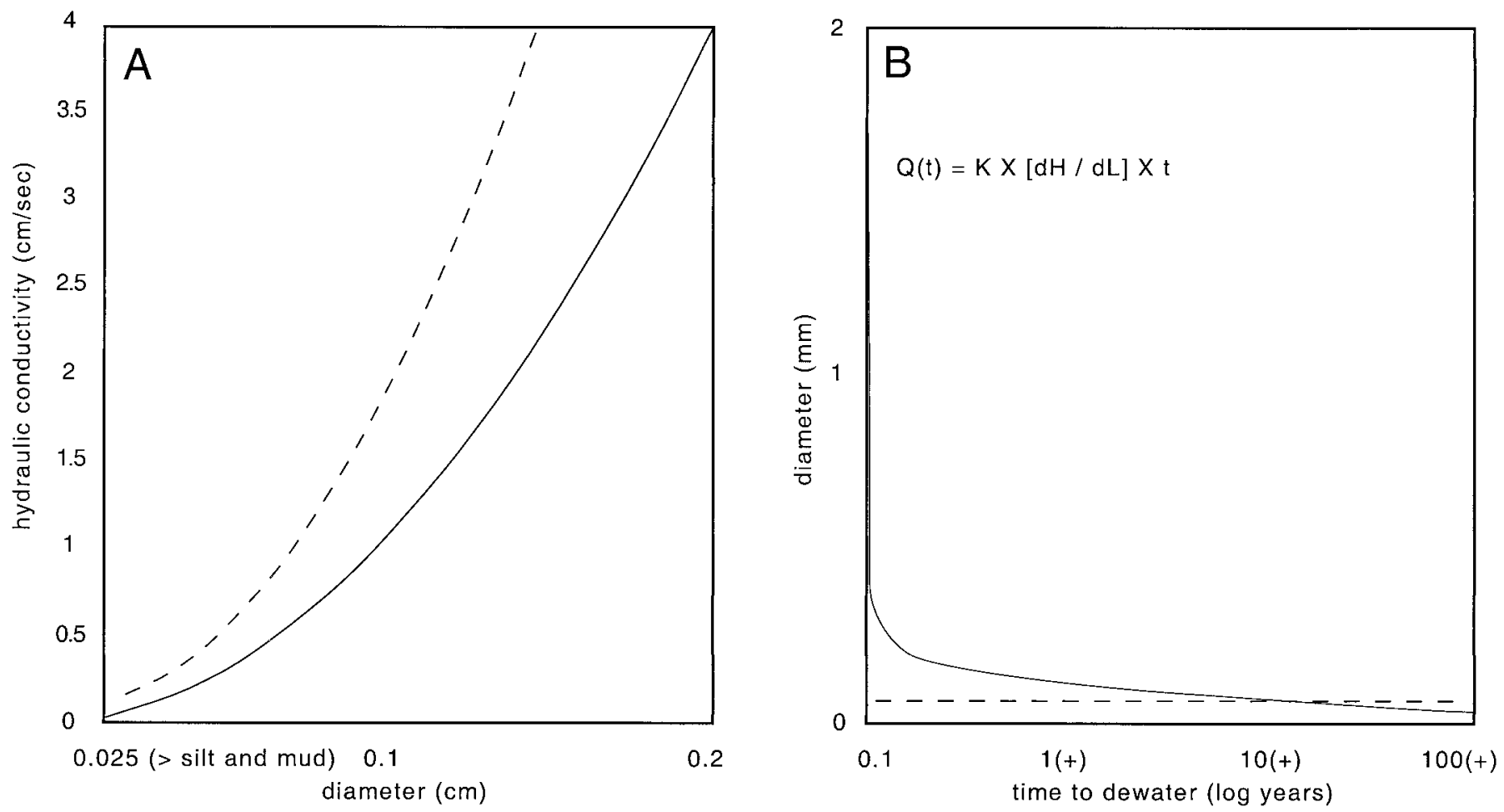

FIG. 7.-Graphs illustrating the relationship between hydraulic conductivity, effective grain size, and the time required to dewater a substrate. A) Hydraulic conductivity versus effective grain size. Hydraulic conductivity was calculated using Hazen's method (Hazen 1911) for sand and was estimated from charts for silt and mud. The values for silt and mud (not shown on the graph) are asymptotic with the $x$ axis. The dashed line approximates the potential error due to initial compaction (from Tokunaga et al. 1994). Note that this relationship is logarithmic. B) Time to dewater the substrate based on a fixed compactional drainage with a hydraulic gradient of $0.001 \mathrm{~m} / \mathrm{m}$. The formula used to generate the curve is inset into the graph and is based on an initial pore-water volume of 50\% and hydraulic conductivity from Part A. The dashed line shows upper silt grain size. Although there is a great deal of error intrinsic to this graph, it adequately demonstrates the profound variability in the dewatering times of sands and muds.

Psilonichnus- and Skolithos-like burrows. Point-bar deposits contain small Gyrolithes-, Planolites-, Palaeophycus-, Arenicolites-, and Skolithos-like traces. The intertidal flat contains Thalassinoides-, Rosselia-, Planolites-, Palaeophycus-, Arenicolites-, and Skolithos-like architectures. Complex and predictable lateral relationships underscore the dependence of bioturbate texture on substrate consistency.

Although the stratigraphic significance of Glossifungites surfaces is well recognized, their dependence on physical parameters such as grain size, initial pore-water content, and sedimentation rates have yet to be analyzed in the geological literature. The temporal significance of such surfaces is therefore unknown. Lower hydraulic conductivities in mud versus sand suggest that muddy substrates take much longer to dewater and are therefore indicative of more significant erosional events. Observations of modern deposits indicate that criteria such as the degree of compaction of Glossifungites ichnogenera, the type of ichnofossils preserved, and the scale of topographic relief on the erosional surface can help reveal the relative importance of firmground assemblages. Exhumed Pleistocene surfaces are generally planar. Modern Glossifungites assemblages in these substrates are undeformed and have excellent sculptings preserved (Fig. 5). Exhumed, modern substrates exhibit decimeter-scale topography (Fig. 6) and contain burrows that relax or collapse if not maintained by the trace maker. This results mainly from a relative patchiness of firmness profiles and an overall difference in the plasticity of modern versus Pleistocene substrates.

Temporally insignificant Glossifungites surfaces (in muddy substrates) are indicative of at least $2 \mathrm{~m}$ of erosion, if the substrate is not subjected to widespread desiccation. At the bay, more significant surfaces consist of exhumed Pleistocene mud that represent a depositional hiatus of at least
$100 \mathrm{ka}$ and are the result of large changes of relative sea level $(>10$ meters; Dupré et al. 1991).

A much larger database will be required to adequately assess the significance of Glossifungites-demarcated discontinuities. Data collection should focus on the nature of bioturbation, age relationships, burial histories, and firmness tests. The most valuable information might still be derived from locations in the modern where these deposits are being colonized.

\section{ACKNOWLEDGMENTS}

Funding of this research was generously provided by the Natural Sciences and Research Council (NSERC) Operating Grant (No. A0816) to S.G. Pemberton, John Van Wagoner at Exxon Production Research, Lee F. Krystinik at Union Pacific Resources, and Grant Wach at Texaco Inc. Many thanks are extended to Stephen Hubbard and Ian Armitage, who assisted with the field work. All the other members of the Ichnology Research Group at the University of Alberta were inestimably helpful in completing the work. Tom Saunders, Ed Clifton, Arjun Keswani, and Al Curran each played a significant role in inspiring this research. The manuscript was vastly improved by the careful reviews of Dr. James MacEachern, Dr. Greg Nadon, and an anonymous reviewer.

\section{REFERENCES}

BRINell, J.A., 1900, II Congress Int. d. Methodes d'essai: Iron and Steel Institute, Journal v. 59 , p. 243.

Bromley, R.G., 1996, Trace Fossils, Second Edition: Suffolk, U.K., Chapman \& Hall, 361 p. CADÉE, G.C., 1998, Influence of benthic fauna and microflora, in Eisma, D., ed., Intertidal Deposits; River Mouths, Tidal Flats, and Lagoons: Boca Raton, Florida, CRC Press, p. 383 402 .

Clifton, H.E., and Phillips, R.L., 1980, Lateral trends and vertical sequences in estuarine sediments, Willapa Bay, Washington, in Field, M.E., Bouma, A.H., Colburn, I.P., Douglas, 
R.G., and Ingle, J.C., eds., Quaternary Depositional Environments of the Pacific coast: Society of Economic Paleontologists and Sedimentologists, Pacific Section, Pacific Coast Paleogeography Symposium no. 4, p. 55-71.

Crimes, T.P., 1968, Cruziana: a stratigraphically useful trace fossil: Geological Magazine, v. 105 , p. $360-364$

Dewherst, D.N., Aplin, A.C., SARda, J.P., AND Yang, Y., 1998, Compaction-driven evolution of porosity and permeability in natural mudstones: an experimental study: Journal of Geophysical Research, v. 103, p. 651-661.

Dupré, W.R., Morrison, R.B., Clifton, H.E., Lajoie, K.R., Ponti, D.J., Powell, C.L., II, Mathieson, S.A., Sarna-Wojcicki, A.M., Leithold, E.L., Lettis, W.R., McDowell, P.F., Rockwell, T.K., UnRuh, J.R., and Yeats, R.S., 1991, Quaternary Geology of the Pacific margin, in Morrison, R.B., ed., Quaternary Nonglacial Geology: Conterminous U.S.: Geological Society of America, Decade of North American Geology, vol. K2, p. 141-214.

Frey, R.W., AND SeIlacher, A., 1980, Uniformity in marine invertebrate ichnology: Lethaia, v. 13 , p. $183-207$.

Gingras, M.G., and Pemberton, S.G., in press, A field method for determining the firmness of various substrates: Journal of Sedimentary Research.

Hazen, A., 1911, Discussions: Dams on sand foundations: American Society of Civil Engineers, Transactions, v. 73 , p. $37-58$.

Hoyt, J.H., AND HeNRY, V.J., 1964, Development and geological significance of soft beach sand: Sedimentology, v. 3, p. 44-51.

Krumbein, W.C., 1959, The "sorting out" of geological variables illustrated by regression analysis of factors controlling beach firmness: Journal of Sedimentary Petrology, v. 29, p. $575-587$.

Kvenvolden, K.A., Blunt, D.J., And Clifton, H.E., 1979, Amino acid racemization in Quaternary shell deposits at Willapa Bay: Washington: Geochimica et Cosmochimica Acta, v. 43 , p. $1505-1520$.

MacEachern, J.A., Raychaudhuri, I., and Pemberton, S.G., 1992, Stratigraphic applications of the Glossifungites ichnofacies: delineating discontinuities in the rock record, in Pemberton,
S.G., ed., Applications of Ichnology to Petroleum Exploration; A Core Workshop: SEPM, Core Workshop 17, p. 169-198.

Pemberton, S.G. And Frey, R.W., 1985, The Glossifungites ichnofacies: modern examples from the Georgia Coast, U.S.A., in Curran, H.A., ed., Biogenic Structures: Their Use in Interpreting Depositional Environments: SEPM, Special Publication 35, p. 237-259.

Pemberton, S.G., and MacEachern, J.A., 1995, The sequence stratigraphic significance of trace fossils: Examples from the Cretaceous foreland basin of Alberta, Canada, in Van Wagoner, J.A., and Bertram, G.T., eds., Sequence Stratigraphy of Foreland Basin Deposits: American Association of Petroleum Geologists, Memoir 64, p. 429-475.

Pemberton, S.G., MacEachern, J.A., and Frey, R.W., 1992, Trace fossil facies models: environmental and allostratigraphic significance, in Walker, R.G., and James, N.P., eds., Facies Models: Response to Sea Level Change: Geological Association of Canada, p. 47-72.

SeIlacher, A., 1964, Sedimentological classification and nomenclature of trace fossils: Sedimentology, v. 3, p. 253-256.

Seilacher, A., 1970, Cruziana stratigraphy of "nonfossiliferous" Palaeozoic sandstones, in Crimes, T.P., and Harper, J.C., eds., Trace Fossils: Geological Journal, Special Issue 3, p. $447-476$

Tokunaga, T., Hosoya, S., Kojima, K., and TosaKa, H., 1994, Change of hydraulic properties of muddy deposits during compaction: Assessment of mechanical and chemical effect: International Association of Engineering Geology, International Congress Proceedings, v. 7 , p. $635-643$.

U.S. Army CoRps of EngineERs, 1975, Willapa River and Harbor navigation project, Washington: Environmental Impact Statement Review Draft, 99 p.

Whitehouse, R.J.S., AND Michener, H.J., 1998, Observations of the morphodynamic behavior of an intertidal mudflat at different timescales, in Black, K.S., Patterson, D.M., and Cramp, A., eds., Sedimentary Processes in the Intertidal Zone: Geological Society of London, Special Publication 139, p. 255-272.

Received 2 December 1998; accepted 18 November 1999. 